\title{
FOLIAR APPLICATION OF SELENIUM, ZINC AND COPPER IN ALFALFA (Medicago sativa L.) BIOFORTIFICATION
}

\author{
Klara PETKOVIĆ ${ }^{*}$, Maja MANOJLOVIĆ ${ }^{1}$, Ranko ČABILOVSKI ${ }^{1}$, Đorđe KRSTIĆ ${ }^{I}$, Zdenko \\ LONČARIĆ ${ }^{2}$, Peder LOMBNAES \\ ${ }^{1}$ University of Novi Sad, Faculty of Agriculture, Trg Dositeja Obradovića 8, Novi Sad, SERBIA \\ ${ }^{2}$ University J.J. Strossmayer in Osijek, Faculty of Agriculture, Vladimira Preloga 1, Osijek, CROATIA \\ ${ }^{3}$ Norwegian Institute of Bioeconomy Research, As, NORWAY \\ *Corresponding author: klaram@polj.uns.ac.rs
}

Received: 08.10.2018

\begin{abstract}
Biofortification of forage crops has an important role in improving the quality of plants used for animal nutrition. The field experiments were conducted in three consecutive years in Subotica, Serbia, in order to investigate the effect of $\mathrm{Se}, \mathrm{Zn}$, and $\mathrm{Cu}$ foliar fertilization on the yield, Se and $\mathrm{Zn}$ contents and nutrient efficiency, as well as on other mineral compositions of alfalfa hay. The treatments were as follows: i) control without fertilization, ii) $5 \mathrm{~g} \mathrm{Se} \mathrm{ha}^{-1}$, iii) $10 \mathrm{~g} \mathrm{Se} \mathrm{ha}^{-1}$, iv) $0.5 \mathrm{~kg} \mathrm{Zn} \mathrm{ha}^{-1}$, v) $1 \mathrm{~kg} \mathrm{Zn} \mathrm{ha}^{-1}$, vi) the combination of these two elements $\left(0.5 \mathrm{~kg} \mathrm{Zn} \mathrm{ha}^{-1}\right.$ and $\left.\mathrm{Se} 10 \mathrm{~g} \mathrm{ha}^{-1}\right)$ and vii) $2 \% \mathrm{Cu}$ solution. The application of $\mathrm{Se}, \mathrm{Zn}$, and $\mathrm{Cu}$ had no effect on dry yield or on crude protein, $\mathrm{P}, \mathrm{K}, \mathrm{Ca}, \mathrm{Mg}, \mathrm{Fe}, \mathrm{Mn}$, Mo, and Co contents in alfalfa hay. However, $\mathrm{Se}, \mathrm{Zn}$, and $\mathrm{Cu}$ fertilization significantly increased the contents of $\mathrm{Se}, \mathrm{Zn}$, and $\mathrm{Cu}$ in alfalfa hay. The results showed that $\mathrm{Se}$ and $\mathrm{Zn}$ contents in plant biomass were significantly correlated with the applied doses of Se $(r=0.99)$ and $\mathrm{Zn}(r=0.99)$. The production years of alfalfa and the weather conditions proved to be significant factors in fertilization efficiency.
\end{abstract}

Keywords: Animal feed, fertilization, fertilization efficiency, microelements.

\section{INTRODUCTION}

Selenium (Se) has not been identified as an essential element for plants (Terry et al., 2000), but it is very important for animal's health. The adequate level of Se $\left(0.1 \mathrm{mg} \mathrm{Se} \mathrm{kg}{ }^{-1} \mathrm{DM}\right)$ in the animal diet is necessary (Gupta, 2008); otherwise, the deficiency may cause a several of disorders such as poor growth, white muscle disease, or infertility (Fisher, 2008). Selenium has a high antioxidant ability and it is integrated into glutathione peroxidase (GPHPx), an enzyme responsible for maintenance of red blood cells and cell membranes (Gupta and Gupta, 2002). According to Gupta and Gupta (2002), the soils containing more than $0.6 \mathrm{mg} \mathrm{Se} \mathrm{kg}^{-1}$ dry matter (DM) will produce forage crops which can satisfy the nutritional needs of animals. In previous studies in the Balkan region, it has been indicated that the soils are deficient in Se (Manojlović and Lončarić, 2017). In the soil samples collected from different forage crops in North and East Serbia, the Se contents were below the specified level, in the range of 0.14-0.57 mg kg-1 (Marijanušić et al., 2017). Also, an inadequate level of Se was measured in the blood of sheep and cows from the Western Balkan region, as reported by Antunović et al. (2010) and Ademi et al. (2015).
Zinc ( $\mathrm{Zn})$ represents a vital element in the nutrition of plants, animals, and humans. Zn deficiency in animals may result in anorexia, abnormalities of the skin, skeletal or reproductive disorders (Suttle, 2010). The Zn requirements for ruminants and monogastric animals are different and range from 40-50; 40; 50-100, and 29-44 mg $\mathrm{kg}^{-1} \mathrm{DM}$ for cows, sheep, pigs, and chicks, respectively (Fisher, 2008). The symptoms of Zn deficiency usually occur due to an insufficient level in feed. The northern part of Serbia (Vojvodina Province) is considered to be a Zn deficient area (Manojlović and Singh, 2012). In a study conducted in Serbia, the $\mathrm{Zn}$ contents in most of the soil samples (total $n=157$ ) were above the specified limit of $0.5 \mathrm{mg} \mathrm{kg}^{-1}$ (DTPA extractable Zn), and only in $13 \%$ of the samples mostly collected in the Vojvodina Province below this limit (Nikolic et al., 2016). According to Marijanušić et al. (2017) the measured Zn contents in all of the samples of forage crops (alfalfa and grasses) in Vojvodina and East Serbia were below $15 \mathrm{mg} \mathrm{kg}^{-1}$.

Copper is an integral part of a large number of enzymes (ferroxidase, lysyl oxidases, tyrosinase, etc.) necessary for the normal functioning of the organism. Copper deficiency in livestock nutrition may lead to anemia, osteoporosis, depigmentation, or other disorders (Suttle, 2010). The sufficiency levels of $\mathrm{Cu}$ in crops used 
for livestock nutrition are 4-10 $\mathrm{mg} \mathrm{kg}^{-1}$ for cattle; $6-10 \mathrm{mg}$ $\mathrm{kg}^{-1}$ for sheep, or an even higher level of $60 \mathrm{mg} \mathrm{kg}^{-1}$ for post-weaning pigs. $\mathrm{Cu}$ content in fodder plants in Serbia varies depending on the site and the plant species and is generally below the established limits for livestock production (Manojlović and Singh, 2012; Marijanušić et al., 2017).

Alfalfa is one of the most valuable forage crops used for animal feed. The importance of alfalfa is due to its high and stable yields of nutritious feed. In addition to a high content of crude proteins, contains high levels of microelements that are important for the growth and development of animals (Radović et al., 2009).

Forage crops represent the natural source of minerals in livestock nutrition (Suttle, 2010). The natural deficiency could be compensated for through numerous measures: biofortification of forage crops (Novoselec et al., 2018), or treatment of animals with injections, mixing with food, etc. (Fisher, 2008). However, a great number of studies have demonstrated the advantage of the organic source of microelements over the inorganic. The organic sources of Se were more efficient in increasing blood Se and blood GPHPx of lambs (Qin et al., 2007), boars (Petrujkić et al., 2014), and beef cows (Slavik et al., 2008). Ao et al. (2009) reported that the antagonism of $\mathrm{Zn}$ and $\mathrm{Cu}$ in the diet of chicks could be avoided by using the organic sources of these elements. Hall et al. (2013) found out that Se fertilized alfalfa $\left(22.5 ; 45.0 ; 89.9 \mathrm{~g} \mathrm{Se} \mathrm{ha}^{-1}\right)$ could improve Se status in the blood of weaned beef calves. Numerous studies have reported that foliar fertilization is an important tool in biofortification of forage crops with Se and Zn (Ceylan et al., 2009; Nawaz et al., 2016; Wang et al., 2013). On the other hand, the literature shows limited information related to the foliar $\mathrm{Cu}$ fertilization of forage crops.
Considering the above mentioned facts that $\mathrm{Se}, \mathrm{Zn}$, and $\mathrm{Cu}$ represent the vital microelements for livestock health maintenance; that forage crops as organic sources of minerals are deficient in $\mathrm{Se}, \mathrm{Zn}$ and $\mathrm{Cu}$ on the territory of Serbia; and that foliar fertilization is an important measure to improve the status of these elements in forage crops; this study was conducted to investigate 1) the effect of foliar fertilization with $\mathrm{Se}, \mathrm{Zn}$, and $\mathrm{Cu}$ on alfalfa yield and the contents of $\mathrm{Se}, \mathrm{Zn}$ and $\mathrm{Cu}$ in alfalfa biomass; 2) the effect of foliar fertilization on the content of other macro and micro elements; and 3) the efficiency of applied fertilizers.

\section{MATERIALS AND METHODS}

\section{Experimental site}

The studies were conducted at a dairy farm in the vicinity of Subotica, Serbia $\left(46^{\circ} 3^{\prime} 39.92^{\prime \prime N}, 19^{\circ} 32^{\prime} 3.77^{\prime \prime E}\right)$ under rainfed conditions from 2014 to 2016. Subotica is situated in the north part of Serbia and the south part of the Pannonian Basin, near the Serbian-Hungarian border. The soil of the experimental site is Calcic Chernozem and the basic physical and chemical properties of the soil are given in Table 1 . The high content of $\mathrm{CaCO}_{3}$ is followed by a high $\mathrm{pH}$ of the soil. The studied soil is in the class of medium humous, optimally provided with phosphorus i.e. moderate provided with plant-available potassium. The concentrations of total (Se and $\mathrm{Mo}$ ) and plant-available macro- $(\mathrm{Ca}$ and $\mathrm{Mg}$ ) and microelements are shown in Table 2. Given the high $\mathrm{pH}$ value of the soil, the lack of certain microelements was expected, however, the experimental plot is sufficiently provided with available $\mathrm{Zn}$ and $\mathrm{Cu}$ (Lindsay and Norvell, 1978). The determined selenium content $\left(0.26 \mathrm{mg} \mathrm{kg}^{-1}\right)$ in soil is below the suggested level $\left(0.6 \mathrm{mg} \mathrm{kg}^{-1}\right)$ for the production of forage crops (Gupta and Gupta, 2002).

Table 1. Basic chemical and physical properties of soil before setting up the experiment

\begin{tabular}{|c|c|c|c|c|c|c|c|}
\hline $\begin{array}{l}\text { cm } \\
\text { depth }\end{array}$ & $\begin{array}{l}\text { Chemical } \\
\text { pH in } \mathrm{KCl}\end{array}$ & $\begin{array}{l}\text { properties } \\
\text { pH in } \mathrm{H}_{2} \mathrm{O}\end{array}$ & $\begin{array}{c}\% \\
\mathrm{CaCO}_{3} \\
\end{array}$ & $\begin{array}{c}\% \\
\text { Organic matter }\end{array}$ & $\begin{array}{c}\% \\
\text { Total N }\end{array}$ & $\begin{array}{l}\text { mg } 100 g^{-1} \\
\mathrm{AL}-\mathrm{P}_{2} \mathrm{O}_{5} \\
\end{array}$ & $\begin{array}{c}\text { mg } 100 g^{-1} \\
\text { AL-K }{ }_{2} \mathrm{O}\end{array}$ \\
\hline $0-30$ & 7.39 & 8.02 & 19.3 & 2.53 & 0.13 & 21.2 & 14.0 \\
\hline $\begin{array}{l}\text { cm } \\
\text { depth }\end{array}$ & $\begin{array}{c}\text { Physical } \\
\% \\
\text { coarse sand } \\
\end{array}$ & $\begin{array}{c}\text { properties } \\
\% \\
\text { fine sand } \\
\end{array}$ & $\begin{array}{c}\% \\
\text { silt }\end{array}$ & $\begin{array}{c}\% \\
\text { clay }\end{array}$ & & & \\
\hline $0-30$ & 3.8 & 44 & 32.6 & 19.6 & & & \\
\hline
\end{tabular}

Table 2. Total and plant-available contents of macro- and microelements in soil

\begin{tabular}{|c|c|c|c|c|c|c|c|c|c|}
\hline depth & $\begin{array}{c}\text { Plant } \\
\% \\
\text { Ca }\end{array}$ & $\begin{array}{c}\text { available } \\
\% \\
\mathrm{Mg}\end{array}$ & $\begin{array}{c}\mathrm{mg} \mathrm{kg}^{-1} \\
\mathrm{Fe}\end{array}$ & $\begin{array}{c}\mathrm{mg} \mathrm{kg}^{-1} \\
\mathrm{Zn}\end{array}$ & $\begin{array}{c}\mathrm{mg} \mathrm{kg}^{-1} \\
\mathrm{Mn}\end{array}$ & $\begin{array}{c}\mathrm{mg} \mathrm{kg}^{-1} \\
\mathrm{Cu}\end{array}$ & $\begin{array}{c}\mathrm{mg} \mathrm{kg}^{-1} \\
\text { Co }\end{array}$ & $\begin{array}{c}\text { Total } \\
\text { mg kg }^{-1} \\
\text { Se }\end{array}$ & $\begin{array}{c}\mathrm{mg} \mathrm{kg}^{-1} \\
\mathrm{Mo}\end{array}$ \\
\hline $0-30$ & 0.15 & 0.008 & 43.0 & 3.36 & 26.6 & 3.33 & 0.50 & 0.26 & 0.32 \\
\hline
\end{tabular}

The total monthly precipitation and mean monthly temperatures during the experiment are given in Figures 1 and 2. Long term average (LTA) represents collected data about monthly temperatures and precipitations in the period 1981-2010 on the weather station Palić. The year
2014 (Figure 1) characterized by a higher rainfall compared to the LTA. However, the problem is the distribution of precipitation during vegetation, which is very unfavourable for spring sowing of alfalfa. The precipitation rate in March was almost twice lower (by 
$16.6 \mathrm{~mm})$ compared to the LTA. The second year of the experiment (2015) was distinguished by the average monthly temperatures at the level of LTA, with slightly higher temperatures in the period from June to September. Regarding the precipitation during the vegetation period, except for May and August, in most other months, it was significantly lower than the average.
In the third year, the temperature conditions were at the same level or slightly higher than the LTA. During the period from May to June, the precipitation rate was close to the LTA, i.e. significantly above from August to October.

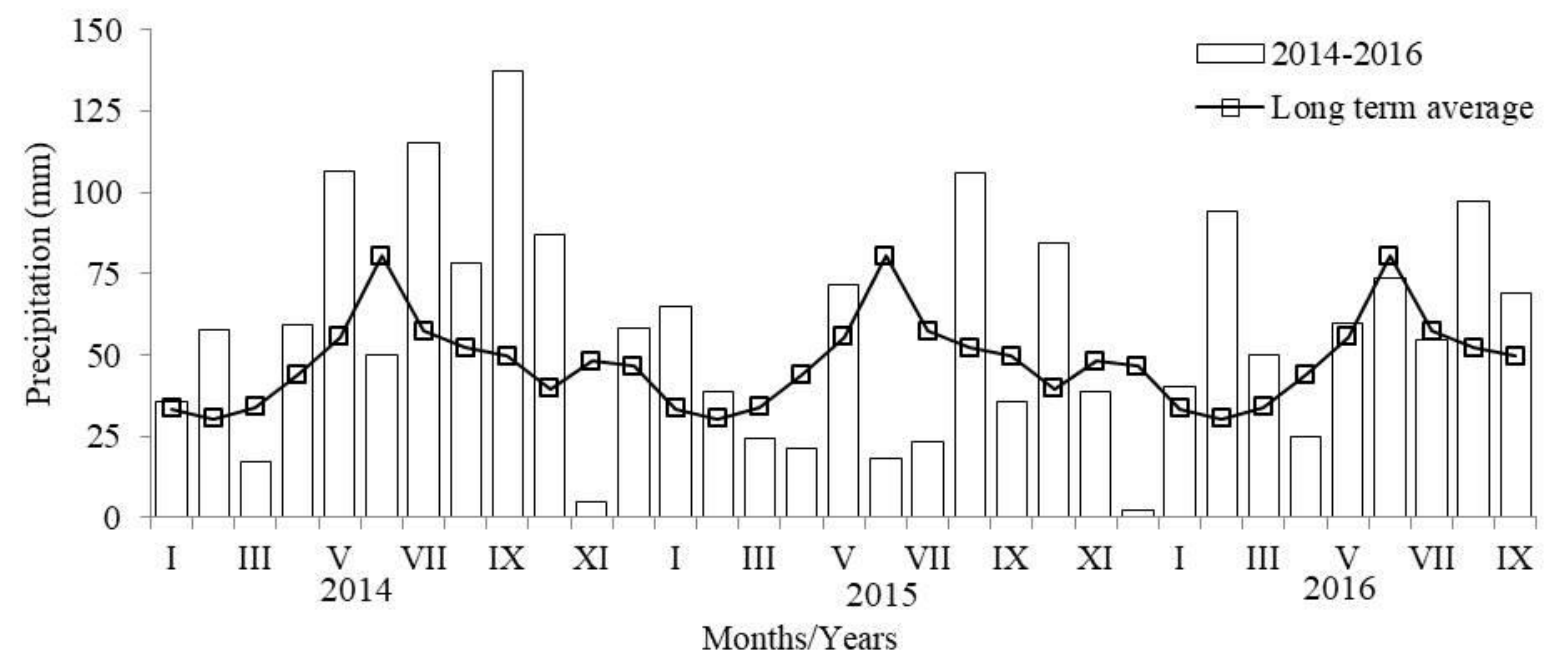

Figure 1. Monthly precipitations in Subotica

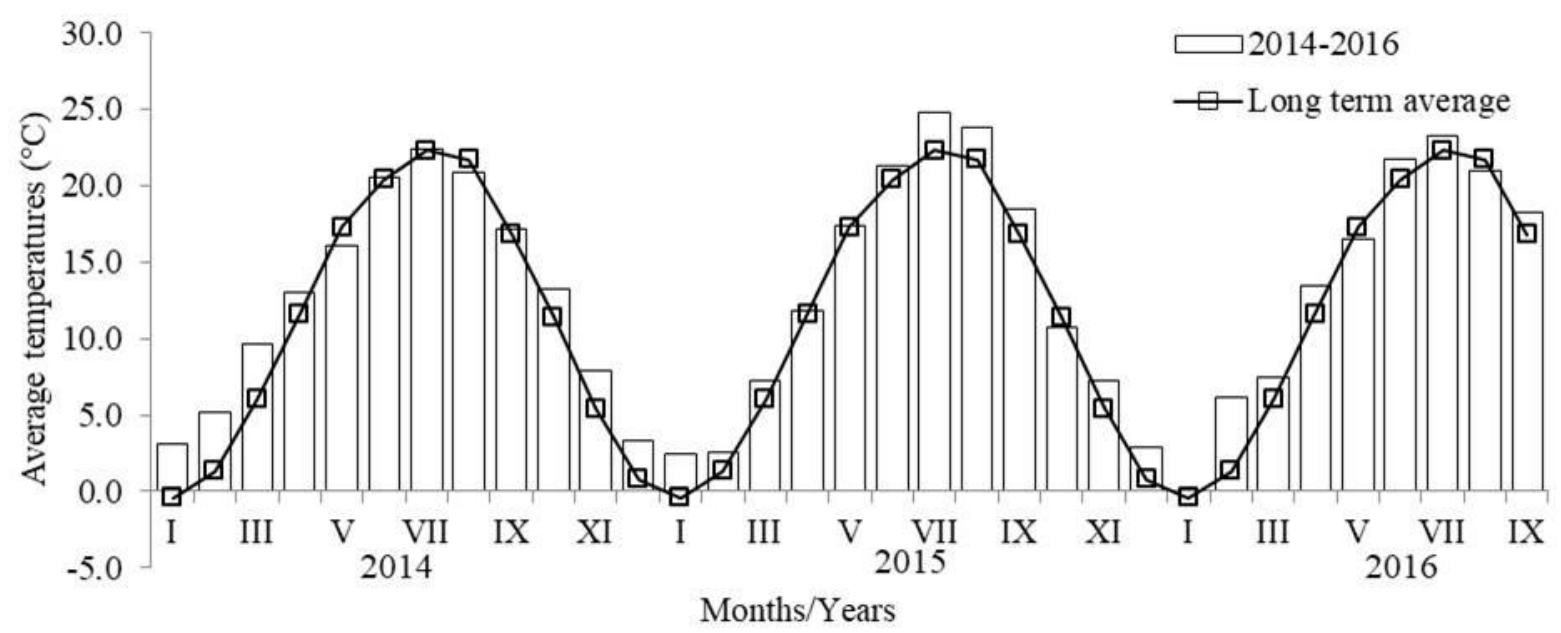

Figure 2. Mean monthly temperatures in Subotica

\section{Experimental design and treatments}

The experiment was conducted as a randomized block design with four replicates and each individual plot was $5 \times 1 \mathrm{~m}$. The treatments were as follows: $i$ ) control without foliar fertilization, ii) Se at two rates of 5 and $10 \mathrm{~g} \mathrm{Se} \mathrm{ha}^{-1}$ (as sodium selenate, $\mathrm{Na}_{2} \mathrm{SeO}_{4}$ ), iii) $\mathrm{Zn}$ at the rates of 0.5 and $1 \mathrm{~kg} \mathrm{Zn} \mathrm{ha-1}$ (as zinc sulphate heptahydrate, $\mathrm{ZnSO}_{4} .7 \mathrm{H}_{2} \mathrm{O}$ ), iv) $2 \% \mathrm{Cu}$ solution (as cupric sulphate, $\left.\mathrm{CuSO}_{4} .5 \mathrm{H}_{2} \mathrm{O}\right)$ and $\left.v\right)$ the combination of Se and $\mathrm{Zn}(0.5$ $\mathrm{kg} \mathrm{Zn} \mathrm{ha}{ }^{-1}$ and Se $\left.10 \mathrm{~g} \mathrm{ha}^{-1}\right)$. The fertilization doses were divided into two foliar applications. The first application was carried out at a plant height of $10 \mathrm{~cm}$, and the second application was seven days after the first. In order to avoid leaf burn, fertilization was performed in the late afternoon. Besides the fertilizer, an adhesive was added during the application. During the foliar fertilization, the plants on the control treatment were treated with distilled water and adhesive. The trial started at the end of March 2014. Sowing was performed by machine at a row spacing of $14.5 \mathrm{~cm}$. The alfalfa cultivar was NS Banat ZMS II with the seeding rate of $20 \mathrm{~kg} \mathrm{ha}^{-1}$. At all experimental plots 50 $\mathrm{kg} \mathrm{N}$ (as ammonium nitrate, 33\% N), $70 \mathrm{~kg} \mathrm{P} 2 \mathrm{O} 5$, and $105 \mathrm{~kg} \mathrm{~K} 2 \mathrm{O}$ ha-1 (as PK 20:30) was incorporated into soil at the time of sowing. 


\section{Sampling}

A soil sample was taken before setting up the experiment (March 2014), from 0 to $30 \mathrm{~cm}$ soil depth.

Alfalfa was harvested at the early flowering stage; at a cutting height of approximately $8 \mathrm{~cm}$. Alfalfa fresh yields were measured in 2014,2015 , and 2016 , by harvesting 1 $\mathrm{m}^{2}$ of each plot and weighing the samples in the field. The samples were dried to constant weight in an air dryer $\left(70^{\circ} \mathrm{C}\right)$ and weighed again to estimate the percentage of dry matter. The dry matter yield was determined on the basis of fresh biomass yield and the percentage of dry matter.

\section{Chemical analysis}

The soil reaction was determined using a soil: water and a soil: $1 \mathrm{M} \mathrm{KCl}$ ratio of 1:2.5 (Mettler Toledo, Five Easy FE 20); the content of $\mathrm{CaCO}_{3}$ volumetrically (ISO 10693:2005) using a Scheibler calcimeter (Hedas, Serbia); the organic matter content was determined by the dichromate method (oxidation with $0.4 \mathrm{~N} \mathrm{~K}_{2} \mathrm{Cr}_{2} \mathrm{O}_{7}$, ISO 14235:2005). The available phosphorus (P) and potassium $(\mathrm{K})$ in the soil samples were extracted with AL solution (0.1 $\mathrm{M}$ ammonium lactate and $0.4 \mathrm{M}$ acetic acid, $\mathrm{pH}$ 3.75) and a soil: solution ratio of 1:20 (AL-method, Egner and Riehm, 1960). The phosphorus content in the extract was determined using a spectrophotometer (Shimadzu UV 2600, Japan) and the K content using a flame photometer (Jenway 6105, USA). The available contents of calcium (Ca), magnesium $(\mathrm{Mg}), \mathrm{Cu}$, manganese $(\mathrm{Mn}), \mathrm{Zn}$, iron $(\mathrm{Fe})$, and cobalt $(\mathrm{Co})$ were extracted using a buffered solution of diethylenetriaminepentaacetic acid triethanolamine (0.005 M DTPA + 0.01 $\mathrm{M} \mathrm{CaCl}_{2}+0.1 \mathrm{M}$ TEA) and a soil: solution ratio of 1:2 (ISO 14870:2001). Measuring was conducted by an atomic absorption spectrophotometer (Shimadzu 6300, Japan). The reference material used for analyses was ISE 973 (Wepal, The Netherlands). Microwave digestion of soil (0.2 g) with hydrofluoric acid $(1 \mathrm{ml})$ and nitric acid $(2 \mathrm{ml})$ in a highpressure system (UltraCLAVE Milestone, Italy) was performed to determine the total contents of Se and Mo. The contents were analyzed by ICP-MS (Agilent 8800 QQQ, USA). Two reference materials were used: DC73324 and NCS ZC73007 (National Analysis Center for Iron and Steel, China).

Since the foliar fertilization was applied only before the first cut, accordingly, the chemical analyses were done only in the samples from that cut. The samples from the first cut for two years (2014 and 2015) were analyzed for crude protein content (CP) and macro- and microelement concentrations ( $\mathrm{P}, \mathrm{K}, \mathrm{Ca}, \mathrm{Mg}, \mathrm{S}, \mathrm{Se}, \mathrm{Cu}, \mathrm{Zn}, \mathrm{Fe}, \mathrm{Mn}, \mathrm{Co}$, and Mo). A cutting mill (Retsch SM 100, Germany) with a heavy-metal free grinding tool was used to grind plant material into powder. Crude protein content was calculated as nitrogen content x 6.25. Nitrogen and sulfur (S) contents were measured using a CHNS analyzer (Vario MACRO Cube, Elementar Analysensysteme $\mathrm{GmbH}$, Germany). In order to determine $\mathrm{P}$ and $\mathrm{K}$, the plant samples were burned in an oven at $550^{\circ} \mathrm{C}$ and then digested with $25 \% \mathrm{HCl}$ (high-temperature dry ashing, Kalra, 1998). The phosphorus content was measured by spectrophotometry while $\mathrm{K}$ content using a flame photometry method. Wet digestion with a mixture of nitric and perchloric acid $\left(\mathrm{HNO}_{3}, \mathrm{HClO}_{4}\right.$ and plant in a 20:5:1 ratio) was used to determine the microelement contents in alfalfa samples (nitric-perhloric acid wet digestion in an open vessel, Kalra, 1998). Reference material was IPE 885 (Wepal, Netherlands) and the measuring was done by AAS. For the analyses of Se and Mo, the plant samples $(0.2 \mathrm{~g})$ were digested with $5 \mathrm{ml}$ of nitric acid and $5 \mathrm{ml}$ of ultrapure water in a high-pressure microwave digestion system (UltraCLAVE Milestone, Italy). The reference material used was wheat flour 1567a and apple leaves 1515 (National Institute of Standards and Technology, USA). The content of Se and Mo was determinated using the ICP-MS method.

Apparent recovery efficiency (ARE, \%) was calculated separately for Se and $\mathrm{Zn}$ according to the following formula (Fixen et al., 2015):

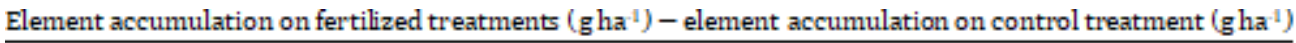
Amount of applied element ( $\left.\mathrm{gha}^{-1}\right)$

The results were subjected to a two-way analysis of variance ANOVA (treatments and years) whereas Fisher's test $(p<0.05)$ was used to detect the significant differences between the treatment means. The statistical analysis was performed using the STATISTICA 13.2 software.

\section{RESULTS \\ Alfalfa yield}

In the first year of the experiment (year of crop establishment) alfalfa achieved only two cuts. In subsequent years, annual dry yields were higher, due to more achieved cuts. Foliar application with $\mathrm{Se}, \mathrm{Cu}$, and $\mathrm{Zn}$ showed no significant effect on alfalfa dry yield compared to control in all years of the experiment (Table
3). The average dry matter yield in the first cut and the annual yield in 2016 were statistically higher than those achieved in 2014 and 2015. Also, statistically significant differences between the measured yields in 2014 and 2015 were observed.

\section{Selenium and zinc content in alfalfa}

Selenium fertilization increased the Se content and its accumulation in alfalfa biomass (Table 4). In comparison with control, a significantly higher Se content was measured on the $10 \mathrm{~g} \mathrm{Se} \mathrm{ha}^{-1}$ treatment in both years. The application of $5 \mathrm{~g} \mathrm{Se} \mathrm{ha}^{-1}$ increased the Se content by 70 and $56 \%$ in 2014 and 2015, but not significantly compared to control. Se accumulation was increased by 42 and $69 \%$ after the application of 5 and $10 \mathrm{~g} \mathrm{Se} \mathrm{ha}^{-1}$ in 2014, but not 
significantly compared to control. Significantly higher nutrient accumulation was measured in 2015 on the treatment with $10 \mathrm{~g} \mathrm{Se} \mathrm{ha}^{-1}$ by $149 \%$ compared to the treatment without fertilization. Correlation analysis showed that $1 \mathrm{~g}$ of Se applied per hectare increased the Se content by $0.40 \mathrm{mg} \mathrm{kg}^{-1} \mathrm{DM}$ of alfalfa biomass in both years (Fig. 3). On all Se applied treatments, apparent recovery efficiency was higher in the second year compared to the first year of the experiment.

Table 3. Effect of fertilization with selenium, copper, and zinc on dry matter yield (t ha $\left.{ }^{-1}\right)$

\begin{tabular}{|c|c|c|c|c|c|c|}
\hline & Treatment & $\begin{array}{l}\text { Yield by cuts } \\
\text { I }\end{array}$ & II & III & IV & $\begin{array}{l}\text { Annual } \\
\text { yield }\end{array}$ \\
\hline \multirow[t]{7}{*}{2014} & control & 1.97 & 1.97 & - & - & 3.94 \\
\hline & Se $5 g$ & 1.62 & 1.71 & - & - & 3.33 \\
\hline & Se $10 \mathrm{~g}$ & 1.76 & 1.67 & - & - & 3.43 \\
\hline & $\mathrm{Zn} 0.5 \mathrm{~kg}$ & 2.70 & 1.82 & - & - & 4.52 \\
\hline & $\mathrm{Zn} 1 \mathrm{~kg}$ & 2.25 & 2.16 & - & - & 4.41 \\
\hline & $\mathrm{Cu} 2 \%$ & 1.51 & 1.94 & - & - & 3.45 \\
\hline & $\mathrm{Zn}+\mathrm{Se}$ & 2.21 & 1.87 & - & - & 4.08 \\
\hline \multirow[t]{7}{*}{2015} & control & 4.30 & 2.73 & 2.31 & - & 9.34 \\
\hline & Se $5 g$ & 4.80 & 2.90 & 1.90 & - & 9.60 \\
\hline & Se $10 \mathrm{~g}$ & 4.56 & 2.50 & 1.88 & - & 8.94 \\
\hline & $\mathrm{Zn} 0.5 \mathrm{~kg}$ & 4.61 & 2.87 & 2.41 & - & 9.89 \\
\hline & $\mathrm{Zn} 1 \mathrm{~kg}$ & 4.76 & 2.96 & 1.88 & - & 9.60 \\
\hline & $\mathrm{Cu} 2 \%$ & 4.10 & 2.65 & 1.93 & - & 8.68 \\
\hline & $\mathrm{Zn}+\mathrm{Se}$ & 3.99 & 2.97 & 2.34 & - & 9.30 \\
\hline \multirow[t]{11}{*}{2016} & control & 4.69 & 2.97 & 1.56 & 1.10 & 10.32 \\
\hline & Se $5 g$ & 5.21 & 3.57 & 2.14 & 1.60 & 12.52 \\
\hline & Se $10 \mathrm{~g}$ & 5.95 & 3.30 & 1.42 & 1.03 & 11.70 \\
\hline & $\mathrm{Zn} 0.5 \mathrm{~kg}$ & 5.91 & 3.17 & 1.83 & 1.02 & 11.93 \\
\hline & $\mathrm{Zn} 1 \mathrm{~kg}$ & 5.04 & 2.77 & 1.91 & 1.05 & 10.77 \\
\hline & $\mathrm{Cu} 2 \%$ & 4.40 & 3.09 & 1.79 & 1.51 & 10.79 \\
\hline & $\mathrm{Zn}+\mathrm{Se}$ & 4.71 & 2.68 & 1.65 & 1.35 & 10.39 \\
\hline & Annual & average & & & & \\
\hline & 2014 & $2.00 \mathrm{C}^{*}$ & $1.88 \mathrm{~B}$ & & & $3.88 \mathrm{C}$ \\
\hline & 2015 & $4.45 \mathrm{~B}$ & $2.80 \mathrm{~A}$ & $2.09 \mathrm{~A}$ & & $9.34 \mathrm{~B}$ \\
\hline & 2016 & $5.13 \mathrm{~A}$ & $3.08 \mathrm{~A}$ & $1.76 \mathrm{~A}$ & 1.24 & $11.20 \mathrm{~A}$ \\
\hline
\end{tabular}

*capital letters represent differences between years

Table 4. Effect of fertilization with selenium, copper, and zinc on Se and $\mathrm{Zn}$ content in alfalfa biomass (first cut)

\begin{tabular}{|c|c|c|c|c|c|c|c|}
\hline & Treatments & $\begin{array}{l}\text { Se content } \\
\mathrm{mg} \mathrm{kg}^{-1}\end{array}$ & $\begin{array}{l}\text { Se } \\
\text { accumulation } \\
\text { g Se ha }^{-1}\end{array}$ & $\begin{array}{c}\text { ARE } \\
\%\end{array}$ & $\begin{array}{l}\text { Zn } \\
\text { content } \\
\text { mg kg }^{-1}\end{array}$ & $\begin{array}{l}\text { Zn } \\
\text { accumulation } \\
\text { g Zn ha }^{-1}\end{array}$ & $\begin{array}{c}\text { ARE } \\
\%\end{array}$ \\
\hline \multirow[t]{7}{*}{2014} & control & $0.37 \mathrm{bc}^{*}$ & 0.77 & - & $15.58 \mathrm{c}$ & $31.20 \mathrm{~cd}$ & - \\
\hline & Se $5 g$ & $0.63 \mathrm{ac}$ & 1.09 & 6.4 & $17.54 \mathrm{c}$ & $28.39 \mathrm{~d}$ & - \\
\hline & Se $10 \mathrm{~g}$ & $0.77 \mathrm{a}$ & 1.30 & 5.3 & $16.01 \mathrm{c}$ & $28.29 \mathrm{~d}$ & - \\
\hline & $\mathrm{Zn} 0.5 \mathrm{~kg}$ & $0.49 a b$ & 1.46 & - & $33.11 \mathrm{~b}$ & $91.70 \mathrm{ab}$ & 12.1 \\
\hline & $\mathrm{Zn} 1 \mathrm{~kg}$ & $0.38 \mathrm{bc}$ & 0.90 & - & $49.90 \mathrm{a}$ & $112.95 \mathrm{a}$ & 8.2 \\
\hline & $\mathrm{Cu} 2 \%$ & $0.21 \mathrm{bd}$ & 0.33 & - & $18.05 \mathrm{c}$ & $27.16 \mathrm{~d}$ & - \\
\hline & $\mathrm{Zn}+\mathrm{Se}$ & $0.53 \mathrm{ac}$ & 0.85 & 0.8 & $29.13 \mathrm{~b}$ & $64.08 \mathrm{bc}$ & 6.6 \\
\hline \multirow[t]{10}{*}{2015} & control & $0.27 \mathrm{c}$ & $1.29 \mathrm{~b}$ & - & $16.13 \mathrm{bc}$ & $68.90 \mathrm{~b}$ & - \\
\hline & Se $5 g$ & $0.42 \mathrm{bc}$ & $1.93 \mathrm{~b}$ & 12.8 & $15.18 \mathrm{bc}$ & $73.10 \mathrm{~b}$ & - \\
\hline & Se $10 \mathrm{~g}$ & $0.68 \mathrm{ab}$ & $3.21 \mathrm{a}$ & 19.2 & $16.48 \mathrm{bc}$ & $75.09 \mathrm{~b}$ & - \\
\hline & $\mathrm{Zn} 0.5 \mathrm{~kg}$ & $0.28 \mathrm{c}$ & $1.44 \mathrm{~b}$ & - & $20.08 \mathrm{ab}$ & $94.16 \mathrm{ab}$ & 5.1 \\
\hline & $\mathrm{Zn} 1 \mathrm{~kg}$ & $0.25 \mathrm{c}$ & $1.31 \mathrm{~b}$ & - & $23.93 \mathrm{a}$ & $115.80 \mathrm{a}$ & 4.7 \\
\hline & $\mathrm{Cu} 2 \%$ & $0.32 \mathrm{c}$ & $1.27 \mathrm{~b}$ & - & $16.06 \mathrm{bc}$ & $64.91 \mathrm{~b}$ & - \\
\hline & $\mathrm{Zn}+\mathrm{Se}$ & $0.75 \mathrm{a}$ & $3.48 \mathrm{a}$ & 21.9 & $19.88 \mathrm{ab}$ & $80.72 b$ & 2.4 \\
\hline & Annual & average & & & & & \\
\hline & 2014 & $0.48 \mathrm{~A}^{* *}$ & $0.94 \mathrm{~B}$ & 4.17 & $25.62 \mathrm{~A}$ & $54.82 \mathrm{~A}$ & 8.97 \\
\hline & 2015 & $0.43 \mathrm{~A}$ & $1.99 \mathrm{~A}$ & 17.97 & $18.25 \mathrm{~B}$ & $81.81 \mathrm{~B}$ & 4.07 \\
\hline
\end{tabular}

*small letters represent differences between treatments within one year

**capital letters represent differences between years 
In 2014 , on the treatments with 0.5 and $1 \mathrm{~kg} \mathrm{Zn} \mathrm{ha}^{-1}$, a significantly higher $\mathrm{Zn}$ content (by 113 and 220\%) was measured compared to control. In the next year of the experiment, a significantly higher $\mathrm{Zn}$ content (by 48\%) was measured only on the treatment with the higher $\mathrm{Zn}$ dose. When comparing $\mathrm{Zn}$ treatments $\left(0.5\right.$ and $\left.1 \mathrm{~kg} \mathrm{ha}^{-1}\right)$ with control, higher nutrient accumulation (by 194 and $262 \%$, respectively) was achieved in 2014 than in 2015

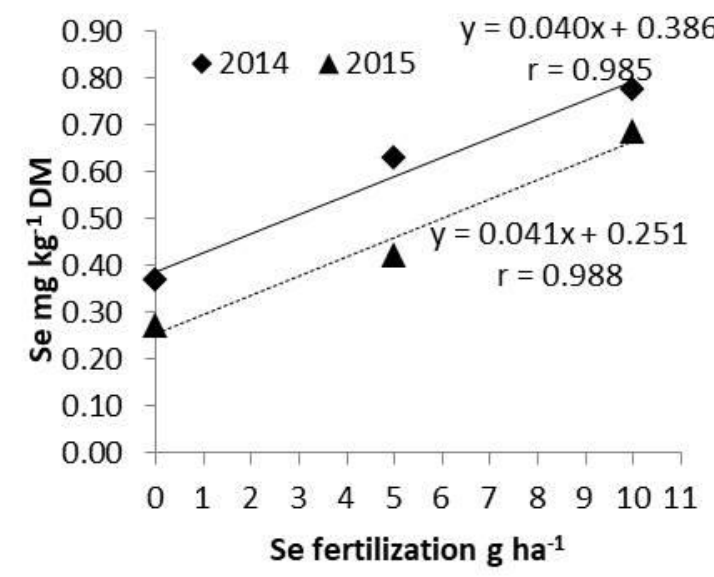

(by 37 and 68\%, respectively). The effect of foliar applied $\mathrm{Zn}$ on its content in alfalfa biomass was different in two years. By applying $0.1 \mathrm{~kg} \mathrm{Zn} \mathrm{ha}{ }^{-1}$, the $\mathrm{Zn}$ content was increased by $34.32 \mathrm{mg} \mathrm{Zn} \mathrm{kg}{ }^{-1} \mathrm{DM}$ in 2014 and by 7.80 $\mathrm{mg} \mathrm{Zn} \mathrm{kg}{ }^{-1} \mathrm{DM}$ in 2015 (Fig. 3). Apparent recovery efficiency was the highest in the first year of the experiment on the treatment with the lower $\mathrm{Zn}$ dose. On average, $\mathrm{Zn}$ fertilization was more efficient in 2014.

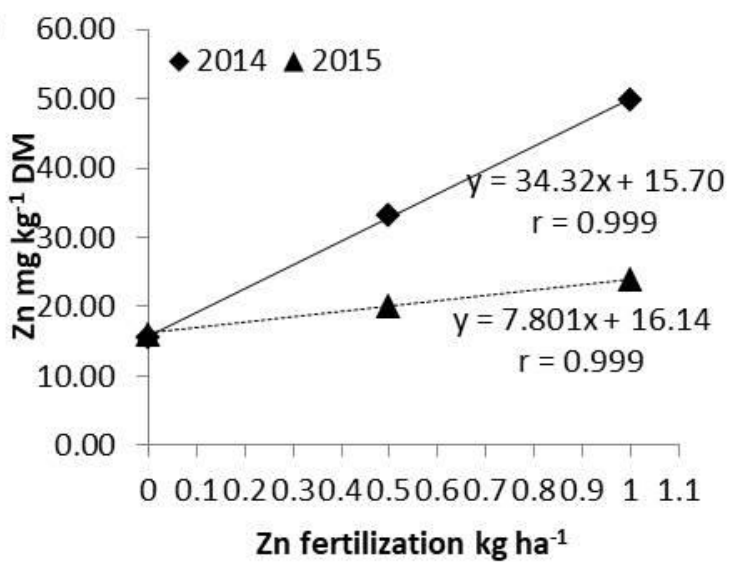

Figure 3. Correlation between Se fertilization and its content in alfalfa biomass and $\mathrm{Zn}$ fertilization and its content in alfalfa biomass

Fertilization with the combination of Se and $\mathrm{Zn}$ (Table 4) increased the Se content in both years (51 and 178\%) compared to control, but it was significantly higher only in 2015. Also, the treatment significantly affected Se removal in 2015. As expected, this treatment positively affected the content of $\mathrm{Zn}$ in alfalfa biomass, but it was significantly higher only in 2014 (by 87\%). On the other hand, there was no significant effect of $\mathrm{Zn}$ removal in both years. The combined fertilization with $10 \mathrm{~g} \mathrm{Se} \mathrm{ha}^{-1}$ and 0.5 $\mathrm{kg} \mathrm{Zn} \mathrm{ha-1}$ did not significantly affect the content and nutrient accumulation of these elements compared to the treatments fertilized with $10 \mathrm{~g} \mathrm{Se} \mathrm{ha}^{-1}$ and $0.5 \mathrm{~kg} \mathrm{Zn} \mathrm{ha}^{-1}$. Apparent recovery efficiency for Se was the highest in 2015 on the treatment with Se and $\mathrm{Zn}$ combined.

\section{Macromineral contents in alfalfa biomass}

Selenium and $\mathrm{Zn}$ fertilization showed no significant effect on the CP content in 2014 (Table 5). In the second year of the experiment, a significant difference was found between the control and $\mathrm{Se}+\mathrm{Zn}$ treatment. In both years, the $\mathrm{S}$ content on the treatments with applied $\mathrm{Se}$ and $\mathrm{Zn}$ decreased compared to control, but not significantly. The exceptions were the treatments with $\mathrm{Zn} 0.5 \mathrm{~kg} \mathrm{ha}^{-1}$ in 2014 and Se $5 \mathrm{~g}$ in 2015. Fertilization with these microelements did not affect the content of $\mathrm{P}, \mathrm{K}, \mathrm{Ca}$, and $\mathrm{Mg}$.

The treatment with $\mathrm{Cu}$ fertilization showed no significant effect on $\mathrm{CP}, \mathrm{P}, \mathrm{K}, \mathrm{S}, \mathrm{Ca}$, and $\mathrm{Mg}$ contents compared to control.

\section{Micromineral contents in alfalfa biomass}

The fertilization of alfalfa with Se and $\mathrm{Zn}$, or these two elements in combination, did not show a significant effect on $\mathrm{Mn}, \mathrm{Co}$, and Mo contents in plant biomass, except on the Fe content (Table 6). In the case of Fe, no significant differences between the control treatment and other treatments were found. However, there were significant differences between the $0.5 \mathrm{~kg} \mathrm{Zn} \mathrm{ha}^{-1}$ treatment and the treatments fertilized with $10 \mathrm{~g} \mathrm{Se} \mathrm{ha}^{-1}$ in 2014.

As expected, $\mathrm{Cu}$ fertilization significantly increased the $\mathrm{Cu}$ content in alfalfa biomass in both years (by 773 and $125 \%$ ). This treatment did not affect the content of other microelements. 
Table 5. Effect of fertilization with selenium, copper, and zinc on CP and macroelement contents in alfalfa biomass (first cut)

\begin{tabular}{|c|c|c|c|c|c|c|c|}
\hline & Treatments & $\begin{array}{l}\mathbf{C P} \\
\%\end{array}$ & $\begin{array}{l}\mathbf{P} \\
\%\end{array}$ & $\begin{array}{l}\mathbf{K} \\
\%\end{array}$ & $\begin{array}{l}\mathrm{S} \\
\%\end{array}$ & $\begin{array}{l}\text { Ca } \\
\%\end{array}$ & $\begin{array}{l}\text { Mg } \\
\%\end{array}$ \\
\hline \multirow[t]{7}{*}{2014} & control & 21.25 & 0.25 & 1.50 & $0.36 \mathrm{a}$ & 3.38 & 0.36 \\
\hline & Se $5 g$ & 21.90 & 0.24 & 1.36 & $0.30 \mathrm{ab}$ & 3.54 & 0.34 \\
\hline & Se $10 \mathrm{~g}$ & 21.63 & 0.23 & 1.28 & $0.31 \mathrm{ab}$ & 3.72 & 0.37 \\
\hline & $\mathrm{Zn} 0.5 \mathrm{~kg}$ & 21.13 & 0.25 & 1.30 & $0.28 \mathrm{bc}$ & 3.51 & 0.31 \\
\hline & $\mathrm{Zn} 1 \mathrm{~kg}$ & 22.85 & 0.24 & 1.62 & $0.32 \mathrm{ab}$ & 3.24 & 0.27 \\
\hline & $\mathrm{Cu} 2 \%$ & 21.79 & 0.25 & 1.44 & $0.30 \mathrm{ab}$ & 3.36 & 0.30 \\
\hline & $\mathrm{Zn}+\mathrm{Se}$ & 21.48 & 0.25 & 1.45 & $0.29 \mathrm{ab}$ & 3.44 & 0.28 \\
\hline \multirow[t]{10}{*}{2015} & control & $17.88 \mathrm{bc}^{*}$ & 0.22 & 1.62 & $0.24 \mathrm{bc}$ & 2.28 & 0.27 \\
\hline & Se $5 g$ & $19.58 \mathrm{ab}$ & 0.21 & 1.43 & $0.32 \mathrm{a}$ & 2.07 & 0.28 \\
\hline & Se $10 \mathrm{~g}$ & $19.90 \mathrm{ab}$ & 0.22 & 1.43 & $0.27 \mathrm{ac}$ & 2.50 & 0.27 \\
\hline & $\mathrm{Zn} 0.5 \mathrm{~kg}$ & $19.02 \mathrm{ab}$ & 0.23 & 1.41 & $0.25 \mathrm{ac}$ & 2.47 & 0.26 \\
\hline & $\mathrm{Zn} 1 \mathrm{~kg}$ & $19.81 \mathrm{ab}$ & 0.21 & 1.27 & $0.27 \mathrm{ab}$ & 2.22 & 0.26 \\
\hline & $\mathrm{Cu} 2 \%$ & $19.54 \mathrm{ab}$ & 0.22 & 1.32 & $0.23 \mathrm{bc}$ & 2.48 & 0.26 \\
\hline & $\mathrm{Zn}+\mathrm{Se}$ & $20.52 \mathrm{a}$ & 0.21 & 1.49 & $0.20 \mathrm{~cd}$ & 2.52 & 0.28 \\
\hline & Annual average & average & & & & & \\
\hline & 2014 & $21.72 \mathrm{~A}^{* *}$ & $0.24 \mathrm{~A}$ & $1.42 \mathrm{~A}$ & $0.31 \mathrm{~A}$ & $3.46 \mathrm{~A}$ & $0.32 \mathrm{~A}$ \\
\hline & 2015 & $19.46 \mathrm{~B}$ & $0.22 \mathrm{~B}$ & $1.42 \mathrm{~A}$ & $0.25 \mathrm{~B}$ & $2.36 \mathrm{~B}$ & $0.27 \mathrm{~B}$ \\
\hline
\end{tabular}

*small letters represent differences between treatments within one year

**capital letters represent differences between years

Table 6. Effect of fertilization with selenium, copper, and zinc on microelement contents in alfalfa biomass (first cut)

\begin{tabular}{|c|c|c|c|c|c|c|}
\hline & Treatments & $\begin{array}{l}\mathrm{Cu} \\
\mathrm{mg} \mathrm{kg}^{-1}\end{array}$ & $\begin{array}{l}\mathrm{Fe} \\
\mathrm{mg} \mathrm{kg}^{-1}\end{array}$ & $\begin{array}{l}\text { Mn } \\
\mathrm{mg} \mathrm{kg}^{-1}\end{array}$ & $\begin{array}{l}\text { Co } \\
\mathrm{mg} \mathrm{kg}^{-1}\end{array}$ & $\begin{array}{l}\text { Mo } \\
\text { mg kg }^{-1}\end{array}$ \\
\hline \multirow[t]{7}{*}{2014} & control & $6.41 b^{*}$ & $417 \mathrm{ab}$ & 54.65 & 0.29 & 1.02 \\
\hline & Se $5 g$ & $7.43 \mathrm{~b}$ & $407 \mathrm{ab}$ & 57.22 & 0.27 & 0.86 \\
\hline & Se $10 \mathrm{~g}$ & $8.27 \mathrm{~b}$ & $353 \mathrm{bc}$ & 59.01 & 0.29 & 0.78 \\
\hline & $\mathrm{Zn} 0.5 \mathrm{~kg}$ & $7.37 \mathrm{~b}$ & $591 \mathrm{a}$ & 61.56 & 0.37 & 0.78 \\
\hline & $\mathrm{Zn} 1 \mathrm{~kg}$ & $9.63 \mathrm{~b}$ & $493 a b$ & 56.21 & 0.38 & 0.86 \\
\hline & $\mathrm{Cu} 2 \%$ & $55.97 \mathrm{a}$ & $491 \mathrm{ab}$ & 58.00 & 0.28 & 0.72 \\
\hline & $\mathrm{Zn}+\mathrm{Se}$ & $8.02 \mathrm{~b}$ & $336 \mathrm{bc}$ & 54.76 & 0.26 & 0.88 \\
\hline \multirow[t]{10}{*}{2015} & control & $7.19 \mathrm{~b}$ & 113 & 26.17 & 0.06 & 0.87 \\
\hline & Se $5 g$ & $7.28 \mathrm{~b}$ & 104 & 27.30 & 0.05 & 0.48 \\
\hline & Se $10 \mathrm{~g}$ & $7.38 \mathrm{~b}$ & 122 & 26.71 & 0.05 & 0.70 \\
\hline & $\mathrm{Zn} 0.5 \mathrm{~kg}$ & $7.26 \mathrm{~b}$ & 129 & 26.13 & 0.15 & 0.59 \\
\hline & $\mathrm{Zn} 1 \mathrm{~kg}$ & $8.03 \mathrm{~b}$ & 112 & 25.54 & 0.10 & 0.51 \\
\hline & $\mathrm{Cu} 2 \%$ & $16.20 \mathrm{a}$ & 120 & 29.46 & 0.18 & 0.55 \\
\hline & $\mathrm{Zn}+\mathrm{Se}$ & $8.97 \mathrm{~b}$ & 119 & 25.45 & 0.12 & 0.47 \\
\hline & Annual average & average & & & & \\
\hline & 2014 & $14.73 \mathrm{~A}^{* *}$ & $441 \mathrm{~A}$ & $57.35 \mathrm{~A}$ & $0.31 \mathrm{~A}$ & $0.84 \mathrm{~A}$ \\
\hline & 2015 & $8.90 \mathrm{~B}$ & $117 \mathrm{~B}$ & $26.68 \mathrm{~B}$ & $0.10 \mathrm{~B}$ & $0.60 \mathrm{~B}$ \\
\hline
\end{tabular}

*small letters represent differences between treatments within one year

**capital letters represent differences between years

\section{DISCUSSION}

\section{Se fertilization}

Fertilization with Se did not show a significant effect on alfalfa and dry matter yield in all years of the experiment. The results were in agreement with the previous studies that foliar fertilization with Se did not affect the grain or biomass yields of rice (Fang et al., 2008), maize (Wang et al., 2013), and timothy (Tremblay et al., 2015). In a pot experiment, Owusu-Sekyere et al. (2013) found out that selenium addition had a slightly negative effect on the fresh weights and biomass accumulation of alfalfa. However, several studies have shown that Se fertilization may positively affect the yield of different crops. In the experiment with wheat, $\mathrm{Se}$ fertigation and foliar spray increased the grain yield of water-stressed plants due to the enhanced production of osmoprotectants and the increased activity of antioxidant enzymes (Nawaz et al., 2015). Similar results have been achieved in the experiment with maize (Nawaz et al., 2016) grown under water deficit conditions. In our research, in the year with the lower amount of precipitation (2015), Se had a slightly positive effect on dry matter yield in the first cut. Selenium fertilization improved Se uptake by alfalfa. As expected, the higher dose showed better results in both years of the experiment. 
The applied dose of Se was linearly correlated with the Se content in alfalfa biomass. In a field experiment with maize, Wang et al. (2013) found out that the Se content in maize grain was highly positively correlated with the rate of Se, both foliar and soil applied. In the study performed using a meta-analysis approach based on 243 experiments (from 1960 to 2014), Ros et al. (2016) found out that fertilization characteristics including formulation, dose, and timing were the driving variables enhancing crop Se uptake. According to the same authors, the highest uptake efficiencies have foliar and selenate based fertilizers.

The applied Se did not significantly affect the content of CP or other macro- and microelements, except in the case of $S$ in 2015. In an experiment conducted by Wang et al. (2013), the contents of other elements than Se in maize grain have not been affected by either soil or foliar application of Se.

\section{Zn fertilization}

The positive effect of $\mathrm{Zn}$ fertilization on alfalfa yield was established in several studies (Grewal 2001; Ceylan et al., 2009; Grewal, 2010). Our study partly confirms these results, because $\mathrm{Zn}$ application slightly increased dry matter yield, but without statistical significance. The reason for this could be the lower doses of $\mathrm{Zn}$ and foliar application in our experiment, in comparison to other studies with alfalfa, where $\mathrm{Zn}$ was applied through soil and in doses of $4 \mathrm{~kg} \mathrm{Zn} \mathrm{ha}{ }^{-1}$ (Grewal 2001; Grewal 2010) or even higher doses of 40,80, $120 \mathrm{~kg} \mathrm{ha}^{-1}$ (Ceylan et al., 2009). Also, Grewal et al. (2001) found out that the same $\mathrm{Zn}$ dose had different efficiency in increasing the yield of different alfalfa cultivars. The concentration of DTPA Zn in soil could be one of the factors that limit the efficiency of $\mathrm{Zn}$ fertilizers. The measured concentration of DTPA Zn in the soil in our experiment was $3.36 \mathrm{mg} \mathrm{kg}^{-1}$ and according to Alloway (2009), it was above the critical concentration of $1.5 \mathrm{mg} \mathrm{kg}^{-1}$ used in the interpretation of soil test. In the experiments with maize and wheat, Wang et al. (2012) concluded that the soil and foliar application of $\mathrm{Zn}$ did not significantly affect biomass or grain yield, due to the soil with sufficient levels of DTPA $\mathrm{Zn}$ (more than $0.48 \mathrm{mg} \mathrm{kg}^{-1}$ ).

In both years of the experiment, the $\mathrm{Zn}$ content was highly correlated with the applied $\mathrm{Zn}$ doses. Also, $\mathrm{Zn}$ fertilization in combination with Se significantly affected the $\mathrm{Zn}$ content in the first year of the experiment. Ceylan et al. (2009) also reported that $\mathrm{Zn}$ foliar fertilization increased the $\mathrm{Zn}$ content, as well as the $\mathrm{CP}$ content, in alfalfa biomass. In our investigation, $\mathrm{Zn}$ fertilization improved the $\mathrm{CP}$ content, especially in the second year, but without statistical significance. The explanation may be the low fertilization dose, as in the case of biomass yield. Zinc accumulation was almost the same in both years, due to the lower yields achieved in the first year of the experiment and a higher $\mathrm{Zn}$ content compared to 2015 with higher yields and a lower $\mathrm{Zn}$ content. Zinc fertilization did not significantly affect the contents of other elements.

\section{Se and Zn fertilization}

According to Sajedi et al. (2011), in corn production under drought stress, Se fertilization is recommended, but not in combination with other microelements, because of their antagonistic effect on the plant and decreased antioxidant activity. The antagonism between selenate and sulfate is well known (Marschner, 1995); therefore, we expected that the applied zinc sulfate would decrease the selenium uptake by alfalfa. However, in our analysis, fertilization with $\mathrm{Se}$ and $\mathrm{Zn}$ in combination did not show a negative effect on the yield, Se uptake, or mineral composition of alfalfa. The application of these two elements in combination had the same results as when they were applied in the same dose separately. Also, in drought year 2015, the CP content and ARE for Se were the highest on this treatment.

\section{Cu fertilization}

Alfalfa belongs to a group of plants with a high sensitivity to copper deficiency (Gupta et al., 2008), but fertilization with $\mathrm{Cu}$ did not show the significant improvement of the other observed elements. Fertilization increased the content of $\mathrm{Cu}$ in alfalfa biomass; however, the toxic level was reached in plants, especially in the first year of the experiment. According to Gupta et al. (2008), the content of $10-70 \mathrm{mg} \mathrm{Cu} \mathrm{kg}-1$ is considered to be toxic to plants and is followed by reduced yield. In a higher concentration than that required by plants, $\mathrm{Cu}$ may cause chlorosis, necrosis, and leaf discoloration, and it may inhibit plant growth (Yruela, 2005). The measured concentration of $\mathrm{Cu}$ in the first year was even higher than the maximum tolerable level of copper $\left(40 \mathrm{mg} \mathrm{Cu} \mathrm{kg}^{-1}\right)$ in feed (Suttle, 2010), and such hay is unusable for livestock nutrition. In the present study, the measured concentration of DTPA $\mathrm{Cu}$ in soil was relatively high and, in combination with fertilization, it led to the toxic level in plants.

\section{Effect of year and weather conditions}

In our experiment, the production year and weather conditions proved to be significant factors in alfalfa production. Alfalfa was sown in the spring of 2014 and due to the lack of precipitation in the period of germination, the establishment was less successful, which also reflected in the yield in all years of the experiment. In Vojvodina, depending on weather conditions, the dry matter yield of alfalfa ranges from $6.4 \mathrm{t} \mathrm{ha}^{-1}$ in a drought year to $25.2 \mathrm{t} \mathrm{ha}^{-1}$ in a year with a higher amount of precipitation (Ćupina et al., 2016). Also, Tucak et al. (2014) have determined that yield varies significantly depending on alfalfa cultivars. In comparison with the first year, higher dry matter yields were achieved in the second $\left(9.335 \mathrm{~kg} \mathrm{ha}^{-1}\right)$ and third year $\left(11.203 \mathrm{~kg} \mathrm{ha}^{-1}\right)$ of the experiment, which represent full harvest years, even though the yields were still lower than reported values. The year 2015 could be considered as a drought year, with a lower amount of precipitation compared to the long-term average, accompanied by high temperatures, while 2016 was more favorable and close to these averages. 
There were no statistical differences in the average Se contents measured on all treatments in 2014 and 2015. Considering only the treatments with Se applied, the higher Se content was found in 2014 but higher nutrient accumulation was achieved in the second year of the experiment. This could be explained by higher dry matter yield achieved in the first cut in 2015 .

The contents of $\mathrm{Zn}$ and the other observed elements were significantly affected by the year i.e. the productivity of alfalfa. In 2015, the lower content of all observed elements was recorded, which might have resulted in higher yields and, therefore, the dilution of elements caused by plant growth.

\section{CONCLUSION}

Foliar fertilization with $\mathrm{Se}, \mathrm{Zn}$, and $\mathrm{Cu}$ could be an important agrotechnical measure for increasing these elements in alfalfa grown in slightly alkaline soil under rainfed conditions. However, $\mathrm{Cu}$ fertilization should be used with caution, because a high dose may cause the toxic levels of $\mathrm{Cu}$ in animal feed. Fertilization with Se and $\mathrm{Zn}$ significantly increased their contents in alfalfa plants and did not have a negative effect on the CP content or other macro and microelements. The fertilization efficiency for Se and $\mathrm{Zn}$ was high, especially in the case of applied Se. The contents of $\mathrm{Se}$ and $\mathrm{Zn}$ in alfalfa biomass are strongly correlated $(r=0.99)$ to the applied doses of Se and $\mathrm{Zn}$, respectively. Foliar fertilization with Se and $\mathrm{Zn}$ in combination could be recommended because it increased Se and $\mathrm{Zn}$ contents in alfalfa and did not show a negative influence on the yield and the content of the other elements. Also, the production year of alfalfa and weather conditions are important factors in the efficiency of applied Se and Zn fertilizers.

\section{ACKNOWLEDGMENT}

This research was supported by the HERD project (2012-2015) Grassland management for high forage yield and quality in the Western Balkans.

\section{LITERATURE CITED}

Ademi, A., E. Govasmark, A. Bernhoft, H. Bytyqi, M. Djikic, M. Manojlović, Z. Loncaric, M. Drinic, A. Filipovic and B.R. Singh. 2015. Status of selenium in sheep and dairy cow blood in Western Balkan countries. Acta Agric. Scand. A Anim. Sci. 65:9-16.

Alloway, B.J. 2009. Soil factors associated with zinc deficiency in crops and humans. Environ Geochem Health. 31:537-548.

Ao, T., J.L. Pierce, R. Power, A.J. Pescatore, A.H. Cantor, K.A. Dawson and M.J. Ford. 2009. Effects of feeding different forms of zinc and copper on the performance and tissue mineral content of chicks. Poult. Sci. 88:2171-2175.

Ceylan, S., H. Soya, B. Budak, H. Akdemir and B.C. Esetlili. 2009. Effect of zinc on yield and some related traits of alfalfa. Turk J Field Crops. 14:136-143.

Ćupina, B., S. Vujić, D. Krstić, B. Djurić, S. Aliu, M. Manojlović, R. Čabilovski and P. Lombnaes. 2016. Performance of legume-grass mixtures in the West Balkan region. Acta Agric. Scand. Sect. B Soil Plant Sci. 7:1-11.

Egner, H., H. Riehm and W.R. Domingo. 1960. Investigations of the chemical soil analysis as a basis for the evaluation of nutrient status in soil. II. Chemical extraction methods for phosphorus and potassium determination. K. Lantbruks. Hogsk. Ann. 26: 195-215 (DE)

Fang, Y., L. Wang, Z. Xin, L. Zhao, X. An and Q. Hu. 2008. Effect of foliar application of zinc, selenium, and iron fertilizers on nutrients concentration and yield of rice grain in China. J. Agric. Food Chem. 56:2079-2084.

Fisher, G.E. 2008. Micronutrients and animal nutrition and the link between the application of micronutrients to crops and animal health. Turk J Agric For. 32:221-233.

Fixen, P., F. Brentrup, T. Bruulsema, F. Garcia, R. Norton and S. Zingore. 2015. Nutrient/fertilizer use efficiency: measurement, current situation and trends. In: Managing water and fertilizer for sustainable agricultural intensification, ed. Drechsel P., Heffer P., Magen H., Mikkelsen R. and Wichelns. D. 8-37, International Fertilizer Industry Association (IFA), Paris, France.

Grewal, H.S. 2001. Zinc influences nodulation, disease severity, leaf drop and herbage yield of alfalfa cultivars. Plant Soil. 234:47-59.

Grewal, H.S. 2010. Fertiliser management for higher productivity of established lucerne pasture. N. Z. J. Agric. Res. 53:303-314.

Gupta, U.C. and S.C. Gupta. 2002. Quality of animal and human life as affected by selenium management of soils and crops. Commun. Soil Sci. Plant Anal. 33:2537-2555.

Gupta, U.C., W.U. Kening and S. Liang. 2008. Micronutrients in soils, crops, and livestock. Earth Science Frontiers. 15:110 125.

Hall, J.A., G. Bobe, J.K. Hunter, W.R. Vorachek, W.C. Stewart, J.A. Vanegas, TC. Estill, D. Wayne, W.D. Mosher and G.J. Pirelli. 2013. Effect of feeding selenium-fertilized alfalfa hay on performance of weaned beef calves. PLoS One 8: e58188. doi: 10.1371 /journal.pone. 0058188

ISO International Organization for Standardization. 2001. ISO14870:2001, Soil quality - Extraction of trace elements by buffered DTPA solution

ISO International Organization for Standardization. 2005. ISO 10693:2005, Soil quality - Determination of carbonate content -Volumetric method

ISO International Organization for Standardization. 2005. ISO 14235:2005, Soil quality - Determination of organic carbon by sulfochromic oxidation

Kalra, Y. 1997. Handbook of Reference Methods for Plant Analysis. CRC Press Boca Raton (USA)

Lindsay, W.L. and W.A. Norvell. 1978. Development of a DTPA soil test for zinc, iron, manganese, and copper. Soil Sci Soc Am J. 42: 421-428.

Manojlović, M. and B.R. Singh. 2012. Trace elements in soils and food chains of the Balkan region. Acta Agric. Scand. Sect. B Soil Plant Sci. 62:673-695.

Manojlović, M. and Z. Lončarić. 2017. Selenium deficiency in regional soils affecting animal and human health in Balkan and other European countries. In: The Nexus of Soils, Plant, Animals and Human Health, ed. Singh, B.R., McLaughlin, M.J. and Brevik, E., 87-98, Schweizerbart, Stuttgart.

Marijanušić, K., M. Manojlović, D. Bogdanović, R. Čabilovski and P. Lombnaes. 2017. Mineral composition of forage crops in respect to dairy cow nutrition, Bulg J. Agric. Sci. 23:204-212.

Marschner, H. 1995. Mineral nutrition of higher plants. 2. ed. Academic press.

Nawaz, F., M. Naeem, M.Y. Ashraf, M.N. Tahir, B. Zulfiqar, M. Salahuddin and M. Aslam. 2016. Selenium supplementation affects physiological and biochemical processes to improve fodder yield and quality of maize (Zea mays L.) under water deficit conditions. Front Plant Sci. 7:1438. 
Nawaz, F., M.Y. Ashraf, R. Ahmad, E.A. Waraich, R.N. Shabbir and M.A. Bukhari. 2015. Supplemental selenium improves wheat grain yield and quality through alterations in biochemical processes under normal and water deficit conditions. Food Chem. 175:350-357.

Nikolic, M., N. Nikolic, L. Kostic, J. Pavlovic, P. Bosnic, N. Stevic, J. Savic and N. Hristov. 2016. The assessment of soil availability and wheat grain status of zinc and iron in Serbia: Implications for human nutrition. Sci. Total Environ. 553:141-148.

Novoselec, J., Ž. Klir, M. Domaćinović, Z. Lončarić and Z. Antunović. 2018. Biofortification of feedstuffs with microelements in animal nutrition. Agriculture. 24:25-34.

Owusu-Sekyere, A., J. Kontturi, R. Hajiboland, S. Rahmat, N. Aliasgharzad, H. Hartikainen and M.M. Seppänen. 2013. Influence of selenium (Se) on carbohydrate metabolism, nodulation and growth in alfalfa (Medicago sativa L.). Plant Soil. 373:541-552.

Petrujkić, B.T., D.S. Šefer, I.B. Jovanović, M. Jovičin, S. Janković, G. Jakovljević, R.C. Beier and R.C. Anderson. 2014. Effects of commercial selenium products on glutathione peroxidase activity and semen quality in stud boars. Anim. Feed Sci. Techno. 197:194-205.

Qin, S., J. Gao and K. Huang. 2007. Effects of different selenium sources on tissue selenium concentrations, blood GSH-Px activities and plasma interleukin levels in finishing lambs. Biol Trace Elem Res. 116:91-102.

Radović, J., D. Sokolović and J. Marković. 2009. Alfalfa-most important perennial forage legume in animal husbandry. Biotechnol. Anim. Husb. 25: 465-475.

Ros, G. H., A.M.D. Van Rotterdam, D.W. Bussink and P.S Bindraban. 2016. Selenium fertilization strategies for biofortification of food: an agro-ecosystem approach. Plant Soil. 404:99-112.
Sajedi, N.A., M.R. Ardakani, H. Madani, A. Naderi and M. Miransari. 2011. The effects of selenium and other micronutrients on the antioxidant activities and yield of corn (Zea mays L.) under drought stress. Physiol. Mol. Biol. Plants. 17:215-222.

Slavik, P., J. Illek, M. Brix, J. Hlavicova, R. Rajmon and F. Jilek. 2008. Influence of organic versus inorganic dietary selenium supplementation on the concentration of selenium in colostrum, milk and blood of beef cows. Acta Vet. Scand. 50:43.

Suttle, N.F. 2010. Mineral Nutrition of Livestock. 4th ed. Wallingford: CABI Publishing.

Terry, N., A.M. Zayed, M.P. De Souza and A.S. Tarun. 2000. Selenium in higher plants. Annu Rev Plant Biol. 51:401432.

Tremblay, G.F., G. Bélanger, J. Lajeunesse, P.Y. Chouinard and É. Charbonneau. 2015. Timothy response to increasing rates of selenium fertilizer in Eastern Canada. Agron J. 107:211220.

Tucak, M., S. Popović, T. Čupić, G. Krizmanić, V. Španić, B. Šimić and V. Meglič. 2014. Agro-Morphological and forage quality traits of selected alfalfa populations and their application in breeding. Turk J Field Crop. 19(1):79-83 .

Wang, J., Z. Wang, H. Mao, H. Zhao and D. Huang. 2013. Increasing $\mathrm{Se}$ concentration in maize grain with soil-or foliar-applied selenite on the Loess Plateau in China. Field Crops Res. 150:83-90.

Yruela, I. 2005. Copper in plants. Braz. J. Plant Physiol. 17:145156. 